\title{
Developing Narrative Text-Based Module for Teaching Reading Comprehension: Focus on Practicality
}

\author{
Safriyani Novitri ${ }^{1}$ \\ Universitas Islam Riau ${ }^{I}$ \\ safriyaninovitri@edu.uir.ac.id ${ }^{l}$
}

\begin{abstract}
This paper shows the function of a narrative text-based module to develop students reading skills. The research design is $R \& D$ (Research and Development), focusing on students' practicality. The researcher tried to find out the analysis and the practicality of the module in designing and implementing reading in a narrative text based-module. The sample was selected from second-semester students at the English Department of FKIP UIR. The students were given a test to be answered to find out the practicality, which consisted of pre-test and post-test. The module provides exercises that encourage the students to develop their reading comprehension. This module combines summary and references in every unit of the module. This module provides a formative test with an answer key at the end of each chapter.
\end{abstract}

\begin{abstract}
ABSTRAK
Makalah ini menunjukkan fungsi modul berbasis teks naratif untuk mengembangkan keterampilan membaca siswa. Desain Penelitian ini adalah $R \& D$ (Research and Development) yang hanya menitikberatkan pada kepraktisan mahasiswa dalam menggunakan modul. Peneliti mencoba untuk mengetahui analisis, dan kepraktisan modul dalam perancangan dan mengimplementasikan dalam membaca teks naratif berbasis modul. Sampel dipilih dari mahasiswa semester dua di Jurusan Bahasa Inggris FKIP UIR. Mahasiswa diberikan tes untuk dijawab dan mengetahui kepraktisan yang terdiri dari pre-test dan post-test. Modul ini juga menyediakan latihan yang mendorong siswa untuk mengembangkan pemahaman bacaan mereka. Modul ini menggabungkan ringkasan dan referensi di setiap unit modul. Modul ini menyediakan tes formatif dengan kunci jawaban di akhir setiap bab.
\end{abstract}

\section{KEYWORDS}

Narrative Text, Module, Teaching Reading.

\section{KATA KUNCI}

Teks Narasi, Modul, Pengajaran Membaca 
Safriyani Novitri ${ }^{l}$

J-SHMIC : Journal of English for Academic

Vol 8, No.2, August 2021

\section{INTRODUCTION}

There are several theories regarding narrative texts, one of them is from Gerot and Wignell (1994). The function of narrative texts is to entertain, and deal with actual or representative experiences in a different way or as a reconstruction of events (Gerot and Wignel, 1994). They further explain the linguistic characteristics of narrative texts, as follows: a). the narrative consists of orientation, complication, and resolution structure. b). The definition of narrative is a time sequence that speaks of a sequence of texts driven by a sequence of events in the world. c). In addition, the narrative uses the past tense, the focus is on the participants themselves, what they did, what happened to them, and then it was described in a story. d). The narrative also uses certain references.

Reading can be interpreted as a thought process, it means something that is obtained from the reader as a person and a process for understanding reading that is closely related to the experience of the reader (Fountas \& Pinnell 2006). It means reading is an activity to gain knowledge based on experience. Therefore, it is necessary to be able to think actively in identifying the contents of the reading text. The ability to understand reading is not only the ability to read each word and sentence in a text but the most important goal in comprehension is the ability to get and convey messages in the text by using own words and relate the information that have been existed in the reader's mind.

This paper emphasizes on the need to make Teaching Reading activity easy and enjoyable through Narrative text-based Module. In Teaching Reading there are some difficulties to comprehend the narrative texts. The narrative text used by the lecturer does not vary so it is difficult to attract students' interest to read and work on practice questions. In addition, lecturers do not have more specific teaching materials to be used by students, especially in teaching narrative texts. Another problem is in materials for teaching reading. It only focused on general text.

Based on the problems above the researcher interest in developing narrative text based-module for teaching reading. The module contains such a guide for students. The module also provides some objectives, activities before starting to read, the instructions for every core activities of reading, and post activities after read. The module also provides exercises that encourage the students to develop their reading comprehension. This module combines summary and references in every unit of the module. This module provides formative test with answer key at the end of each chapter.

Clay (2001) defines that reading is getting the idea, activity which relate to problemsolving in increasing the strength and the flexibility when it is more drills. This means reading as an active thinking process in identifying the content of readers who are involved in an activity that makes conclusions from what they have understood from the reading topic.

Then in order to build problem-solving, reading involves an active cognitive process which integrated with other skills (speaking, listening and writing). We can conclude that reading is a kind of an active process of extracting information from reading texts.

Neil (1992) says that reading comprehension is an effort to find new knowledge from the context that is read and connected with sources that have been found so that it becomes new knowledge. This means that reading is an interesting activity where we can combine the 
experience of the old into a new meaning and be able to know the contents of the text that is read in detail.

Samuels, 2006 explains that reading is an effort to find pleasure, where by reading, thoughts and feelings become open so that they get freshness in thinking. The results by reading can provide new references in providing opinions and comments. Basically, people read according to his pleasure what he likes then he will enjoy it because reading is his pleasure. Based on the explanation above reading is interesting activity and can be happy to do it.

Eagleton (1996) states the same opinion about the purpose of reading when people read poetry books, novels, then someone will indirectly enter the world of reading that is read and it will be very enjoyable for readers because by reading they can find something fun. In this case, by reading a lot, especially those related to foreign languages, a person will master skills in building vocabulary and reading skills in ESL and EFL. There are so many benefits that can be obtained from a lot of reading, especially for students who want to continue their education abroad, by reading a lot of books the opportunity to continue their education abroad will be easier, not only that, with reading insight one can also get a more professional good job.

Williams (2003) explains that students who are more active in reading will get more information and more actual news because the insights gained will be wider than students who read a little. So many tasks will be completed more quickly by reading more so that the questions given will immediately get answers with books that are read, especially in terms of learning a language.

Rosenblatt (1997) describes that people prefer reliable written sources of information rather than information through recorded media because written information is more complete and clear, such as consisting of facts, days, and dates of information obtained. Text obtained through writing will be easier to reach the reader. Skills with reading and written media are currently still a skill that is widely used in terms of finding and describing facts and written sources are more used as references for students.

In purposes of reading, Doff (1997) says that the purpose of reading are finding out, clarifying, checking, the readers' idea. Based on this statement that through reading activity which they can read what ever they want and reading is a process to get knowledge.

Similar opinions are described by several experts about reading texts, each person will differ from one person to another in making meaning in the text. Because each person has a different background and different experiences and schemes in reading. So that everyone will have varying opinions and perceptions after reading and taking the meaning of a text (Nuttall, 1996.

When someone does a reading activity, at that time there is also an interaction between the writer and the reader. Such as through the media of books, journals, or texts with various genres. The texts that have been read will increase the reader's understanding based on knowledge of the texts that have been understood.

In this study, the researcher developed a module that contains teaching reading materials by using the narrative text-based module. The writer realizes that students prefer reading narrative texts because they are entertaining and easy to understand by students. Narrative texts contain events that usually occur, one's life experiences, and sometimes tell 
reconstructed events that are repeated according to the truth of the facts that occurred (Gerot and Wignell, 1994).

The narrative text describes events in chronological order and story sequences according to the sequence of events. The language features of the text are: a). Narrative is consists of orientation, complication, resolution structure. b). Narrative is sequenced in time which talks about the order of the text is driven by the order of event in the world. c). Narrative uses past tense, the focus is on participants (what they did what happened to them). d). Narrative uses specific reference.

Meanwhile, Gerot and Wignell (1994) state that narrative focuses on five important generic structures namely:

1. Orientation: this structure is to arrange the scenes in the story and introduce the characters in the story.

2. Evaluation: this structure describes the situation in the story which includes happy, sad, night, and day.

3. Complications: in the middle of the narrative text there is a conflict that causes problems or crises.

4. Resolution: in this section, the problem in complications has been resolved, whether it is good or bad.

5. Re-orientation: the end of the story, sad ending or happy ending.

In general, the generic structure of narrative text consists of three stages, namely orientation, complication, and ending with a resolution. These three structures are integrated as a whole to make a complete story. Each structure has a different role. The orientation of introducing the characters in the story sets the scene so that the reader can know who, when, what, and where the story takes place. Complications tell the conflicts and problems that occur in the narrative story and the reader will know how the characters in the story resolve the conflict. Resolution is a crisis that occurs in complications whether it will end well or otherwise end badly, then proceed with re-orientation which is the end of the story.

Prastowo (2011) explains the five benefits of a module. First module is as selfinstructional materials. The module is an interesting teaching material and can improve students' ability to learn because by using the module students can learn on their own.

Second is module as clarity of information. The information and explanations in the module are very clear. Module it means of teaching materials to explain the lessons well and easily understood by learners appropriate based on their level of knowledge and their age. While the explanatory function is also attached to the educators. Therefore, the student can serve as a substitute for the function or role of the facilitator/educator.

Third is an evaluation tool. By using it, the students can produce their learning outcomes. Students' learning material mastery can be measured after they have done doing drills or practices in the module. Therefore, module also functions as an evaluation tools.

Fourth is variety material for students, the module consists of various materials that can be studied by students, the material provided is complete and makes it easier for students to learn all the lessons contained in the module. 
Fifth is systematic. It means that the module is defined as learning material that is easy for students to learn, because the content of the module is presented more systematically and starts from the instructions for using the module, explaining the material, then continuing with the conclusion and last exercises, and the last page of the module, there is an answer key so that students can see the correct answer of the practice questions.

\section{METHOD}

The researcher interested in choosing IDI model, because IDI (Intrusctional Development Institude) which explain by Nana (1997) addresses instruction as an entire system, focusing on the interrelationship between context, content, learning and instruction.

The research should start with front - end analyses that consist of knowing what teaching materials needed, continuing with prototype design and end with judgment of the product. The developmental research procedures as the folowing:

\section{Define}

This stage is conducted to get information of real condition. This step is known as need assessment stage. This step is conducted through these following stages:

a. Analyzing the syllabus of the second semester collage students, to know what material taught appropriately with the standard competence and basic competence for teaching reading.

b. Reviewing several teaching materials, to know the appropriation of the content of the materials, way of sending evaluation system with standard competence and basic competence of reading.

c. Reviewing several literatures about reading text. And to find out the material used by lecturers in teaching reading to what extent the reading module is applied.

d. Interviewing the colleagues about the application of modules in teaching reading and researcher interviews some lectures who teach reading at Islamic University of Riau in order to collect information about the application of teaching reading and teaching reading materials used at collage.

e. Analyzing Islamic University of Riau students' characteristics as the basic awareness in developing the teaching materials. It is done to make the instructional materials that should be conducted understood easily by the students.

\section{Design}

Prototype design is the design source stage and the all elements should be used so that at the development stage does not appear too many things beyond the predictions and was able to create the valid, effective and relevant product. Munir (2008) states that prototype design aims to determine the element that need to be loaded into the developing cooperative learning based module for teaching reading.

Several stages should be applied in this design. The first stage is to examine theories about the development of cooperative learning - based modul for teaching reading that should be developed. After mastering the related theory with the development of the process cooperative learning - based module for teaching reading, researcher then continue to work 
Safriyani Novitri ${ }^{1}$

J-SHMIC : Journal of English for Academic

Vol 8, No.2, August 2021

develop draft of it based on relevant theories that have been studied. After it has been developed, the draft must be reviewed repeatedly by the researcher or assisted by peers (peer review).

\section{Develop}

Next, after analyzing and summarizing the result, the researcher developed a product by doing design. After that validated by the validator, then some revisions arise. This step the process of narrative text-based module was made with a measured aspect based on a particular design, then consulted with the validator. Validator consists of 5 experts; 2 linguistic lecturer and 3 English pratitioners by administering questionnaires that contain items that include didactic terms, contruction and technical.

\section{FINDING AND DISCUSSION}

After calculating the results of Pre-test and post-test. It is shown that the students' reading comprehension achievement improved after using narrative text module. The improvement of the students' score can be seen in the following table:

Table 1

The Result Score of Narrative Reading Module

\begin{tabular}{|l|c|c|c|}
\hline \multirow{2}{*}{ No } & \multirow{2}{*}{ Name of Students } & \multicolumn{2}{|c|}{ Score } \\
\cline { 3 - 4 } & & Pre-Test & Post-Test \\
\hline 1 & RAY & 60 & 85 \\
\hline 2 & FR & 60 & 90 \\
\hline 3 & WR & 45 & 75 \\
\hline 4 & RD & 50 & 85 \\
\hline 5 & NW & 45 & 75 \\
\hline 6 & SP & 65 & 85 \\
\hline 7 & RSA & 50 & 80 \\
\hline 8 & ZM & 50 & 80 \\
\hline 9 & IPP & 60 & 80 \\
\hline 10 & MS & 60 & 85 \\
\hline 11 & NL & 45 & 75 \\
\hline 12 & ATK & 45 & 75 \\
\hline 13 & AR & 50 & 70 \\
\hline 14 & DSS & 60 & 80 \\
\hline 15 & NR & 70 & 85 \\
\hline 16 & MF & 45 & 75 \\
\hline 17 & RN & 50 & 80 \\
\hline 18 & SL & 50 & 75 \\
\hline 19 & SN & 60 & 85 \\
\hline 20 & EF & 65 & 80 \\
\hline
\end{tabular}




\begin{tabular}{|l|c|c|c|}
\hline 21 & SY & 45 & 75 \\
\hline 22 & RK & 50 & 75 \\
\hline 23 & APV & 70 & 80 \\
\hline 24 & LAR & 50 & 75 \\
\hline 25 & ASH & 45 & 70 \\
\hline 26 & DW & 65 & 80 \\
\hline 27 & AH & 60 & 75 \\
\hline 28 & AG & 65 & 75 \\
\hline 29 & DPE & 65 & 80 \\
\hline 30 & EHH & 65 & 80 \\
\hline 31 & EMS & 65 & 85 \\
\hline 32 & FN & 50 & 75 \\
\hline 33 & FM & 50 & 80 \\
\hline 34 & HD & 65 & 75 \\
\hline 35 & IS & 60 & 75 \\
\hline 36 & NS & 50 & 70 \\
\hline 37 & RM & 55 & 75 \\
\hline 38 & SHA & 65 & 80 \\
\hline & Mean Score & 62,5 & 82,5 \\
\hline
\end{tabular}

Table 1 shows the result score of formative test from the pre-test and post-test, there was an improvement result score pre-test mean score was 66,5 and post-test mean score was 82,5 and the improvement score was 16 for formative test of narrative text-based module. The students in pre-test who got score $<65$ were twenty seven students, the other eleven students got $>65$. After implementing a Narrative text-based Module at second semester students of FKIP-UIR, there was a significant effect of improvement score. There were still 18 students who got score 70 until 75 and there are 20 students got $>80$.

Based on the results of research the narrative text-based module that can improve students' reading comprehension. There were 20 students with an average post-test score of 82.5 from an average pre-test score of 62,5 . The other 18 students received an average posttest score of 75 from an average pre-test score of 82.5. This shows that the module-based narrative text is very helpful for students in understanding narrative texts.

During the learning process, the students were asked to give the question to the lecturer, find the information of the text, and argue their argumentation about the reading passage. In this opportunity, the lecturer provides the information for the students. However, the students must work hard to find the solution in learning process. Some time the students are difficult about the text and their take note and write important note, but just conclusion in oral discuss in Indonesia language

The students are motivated by some activities such as stimulating of students' curiosity, because after read the text in module the students interest to read and answer the entire question, in order to be understood about the text. They are answer the entire question and predict the question based on information in the module. The students read the module with load and explain about their knowledge about the text after that the students write summaries. The students answering the question after read all the texts, and after understand 
Safriyani Novitri ${ }^{1}$

J-SHMIC : Journal of English for Academic

Vol 8, No.2, August 2021

about the text means.. Thus the end of each session, the students were given chance to deliver their ideas in group about the reading text.

\section{CONCLUSION}

The module was designed with the key answer for students. The key answer led the students to be easy to assess the students worksheets. Each unit was completed with key answers. The module was designed to be the guidance for lecturer to use the students' module. It contained the sequence steps in using module, of teaching and how to do the evaluation.

Every topic in each unit was designed by analyzing the syllabus content and followed the reading matter. Therefore, each unit included a resource page included websites used in lesson in the unit. The module consisted of a variety of written materials that were used for independent study. The module should be used as a substitute for the function of teaching materials educators.

The discussion of this part was mainly concerned with the development of products which had been explained above. The reseacher designed the products based on the components of the module. The topic followed the syllabus designed and the activities corresponded with the content steps of module.

\section{REFERENCES}

Clay, M.M. 2001. Change over time in children's literacy development. Auckland: Heinemann.

Doff, Adrian. 1997. Teach English, a training course for teachers (trainer's handbook). London: cambridge university press in association with the british council.

Eagleton, T. 1996. Literary theory: An introduction. London: Blackwell.

Fountas, I.C. \& Pinnell, G.S. 2006. Guided Reading: Good First Teaching for All Children. Portsmouth: Heinemann.

Gerot Linda and Peter Wignell. 1994. Making Sense of Functional Grammar. Sydney: Antipodean Educational Enterprise."

Munir. 2008. Kurikulum Berbasis Teknologi Informasi dan Komunikasi.Bandung: Alfabeta.

Nuttall, C. 1996. Teaching reading skills in a foreign language (2nd edition). Oxford: Heinemann.

O'Neill, S.P. 1992. Metacognitive strategies and reading achievement among developmental students in an urban community college. Reading-Horizons.

Prastowo, Andi. 2011. Panduan Kreatif Membuat Bahan Ajar Inovatif. Jogjakarta: DIVA Press.

Rosenblatt, L. 1997. Literature as exploration. New York: Appleton-Century.

Samuels, S. J. 2006. Toward a model of reading fluency. In S. J. Samuels \& A. E. Farstrup (Eds.), What research has to say about fluency instruction (pp. 24-

46).Newark, DE: International Reading Association.

Sugiyono. 2010.Metode Penelitian Pendidikan Pendekatan Kuantitatif, dan RD. Bandung: Alfabeta. 